\title{
VIAJE Y ROMANCE EN CANARIAS: EL DISCURSO DEL PARAÍSO EN DOS NOVELAS PUBLICADAS EN LOS ESTADOS UNIDOS*
}

\author{
M. ${ }^{a}$ Isabel González Cruz \\ Universidad de Las Palmas de Gran Canaria
}

\section{RESUMEN}

Reconocidas como uno de los destinos favoritos de una gran variedad de viajeros, las Islas Canarias han inspirado un considerable número de publicaciones. Aunque la amplia bibliografía inglesa sobre Canarias recoge sobre todo escritos de autores británicos, se han detectado también algunas obras publicadas en los Estados Unidos, tanto por novelistas como por científicos norteamericanos. La reciente localización y posterior estudio interdisciplinar de un corpus de novela rosa inglesa ambientada en Canarias nos ha permitido confirmar que en este tipo de textos las islas suelen representarse como un marco paradisíaco, ideal para el romance. En este artículo examinaremos el discurso del paraíso que desarrollan dos textos cuyos protagonistas son estadounidenses que visitan y describen las islas, donde viven sus historias de amor. Son las novelas de Nancy Kennedy (1979) y Robin Jones Gunn (2011), dos obras de ficción, si bien la última proporciona evidencias de varias visitas reales a Gran Canaria realizadas por la autora.

Palabras Clave: viajes, romance, discurso del paraíso, bibliografía inglesa sobre Canarias.

\section{TRAVEL AND ROMANCE IN THE CANARIES: PARADISE DISCOURSE IN TWO NOVELS PUBLISHED IN THE UNITED STATES}

\section{Abstract}

The Canary Islands, a favorite destination for a wide range of travelers, have inspired a considerable number of publications. Texts by British authors abound in the numerous English bibliography on the Canaries, but some works published in the United States, both by American novelists and scientists, have also been detected. After compiling and studying a corpus of English popular romance fiction novels set in the Canaries, we have been able to confirm that this type of text tends to portray the islands as a paradise, an ideal location for romance. This paradise discourse will be our focus of attention in this paper. The protagonists of the two texts analyzed here are Americans who visit and describe the island where they live their romances. Nancy Kennedy's (1979) and Robin Jones Gunn's (2011) novels are works of fiction, though the latter includes aspects from the real trips the author made to Gran Canaria.

Keywords: travel, romance, Paradise discourse, English bibliography on the Canaries.

DOI: http://doi.org/10.25145/j.refiull.2019.38.007 


\section{INTRODUCCIÓN}

Conocidas mundialmente como destino turístico por las bondades casi perennes de su clima, las Islas Canarias han llamado la atención de numerosos viajeros y escritores desde la Antigüedad clásica. Como es sabido, las relaciones anglocanarias a lo largo de la historia han sido particularmente estrechas con el Reino Unido (Bethencourt Massieu 1991; Davies 1987, Fernández-Armesto et al. 1995, García Pérez 1988, González Cruz 1995, entre otros). Igualmente importante, aunque quizá menos conocida, es la conexión isleña con los Estados Unidos, tras los vínculos establecidos con la emigración canaria para la fundación de ciudades en territorio norteamericano (Balbuena 2007, Din 1999, Lipski 1990, Pérez 2011, Santana y Sánchez 1993, etc.) ${ }^{1}$. En trabajos anteriores (González Cruz 2002, 2006, 2008, 2009, 2010, 2011a) hicimos referencia a algunos autores que publicaron en los Estados Unidos estudios de carácter científico, relatos de viaje y obras de ficción relacionados con Canarias ${ }^{2}$. En este artículo examinaremos dos obras pertenecientes al corpus que se está compilando y estudiando para el Proyecto de Investigación FFI2014-53962-P: las novelas de Nancy Kennedy (1979) y Robin Jones Gunn (2011). Aunque un tanto diferentes en cuanto a tipología y fecha de publicación, las dos constituyen ejemplos de narrativa romántica, pues en ambas se desarrollan relaciones amorosas como parte principal del argumento. Si la de Kennedy es una típica novela rosa, la de Gunn podría adscribirse a la denominada chicklit, aunque ambas admiten otras lecturas. Una de esas perspectivas posibles para el análisis es la del relato de un viaje, con varias interesantes coincidencias. En primer lugar, comparten el mismo destino, Gran Canaria, y el mismo punto de partida, San Francisco (California), donde se desarrolla parte de la acción. Se trata, además, de un viaje de descubrimiento para las protagonistas femeninas, descubrimiento de su identidad personal (y espiritual), y de redescubrimiento del amor. Por otro lado, a mbas autoras recurren al uso frecuente de hispanismos para construir y expresar la idea de la otredad y el discurso del paraíso, que se nutre de comentarios y descripciones mediante un lenguaje evocador. Este último aspecto es el que nos proponemos estudiar aquí.

* Agradecemos al MINECO (Ministerio de Economía y Competitividad del Gobierno de España) la financiación para la ejecución del Proyecto interdisciplinar FFI2014-53962-P, del que surge este artículo.

${ }^{1}$ Son los vínculos que intenta estudiar y mantener el proyecto cultural CISLANDERUs, sobre los descendientes canarios de los Estados Unidos. El término representa la unión de dos culturas: CANARY + ISLANDER + Us, jugando con las siglas de Estados Unidos en inglés (U.S.), letras que también forman el pronombre personal us. El proyecto pretende reunir a los canarios de uno y otro lado mediante la investigación y la realización de exposiciones itinerantes ( $c f$. https://www.cislanderus.com).

${ }^{2}$ Nos referimos a las siguientes obras: Alice Carter-Cook, «The Aborigenes of the Canary Islands», American Anthropologist 3 (1900): 451-93; Archibald J. Cronin, Gran Canary. A Novel (1933); Paul Eldridge, Tales of the Fortunate Isles (1959); Earnest A. Hooton, «The Ancient Inhabitants of the Canary Islands", Harvard African Studies 7 (1925); Richard Walter, Canary Island Adventure. A Young Family's Quest for the Simple Life (1956). 
Una diferencia importante entre las dos publicaciones radica en que, mientras que la obra de Gunn proporciona evidencias ${ }^{3}$ de que la autora visitó realmente la isla, no ya una sino tres veces, en el caso de Secret Longings, aunque se mencionan y describen lugares y circunstancias insulares, no hay constancia de que el texto sea fruto de un viaje real; más bien hemos encontrado algún dato erróneo (o impensable) que nos lleva a plantearnos la posibilidad de que la autora no haya viajado para conocer las islas antes de escribir su novela. Otra diferencia es que los protagonistas de esta novela hacen también una corta visita a las islas de Tenerife, Lanzarote y El Hierro; mientras que en Canary Island Song Gran Canaria es el único destino. En el siguiente epígrafe describiremos brevemente la línea argumental principal de cada obra, resumiendo los rasgos más relevantes del marco literario concreto al que se adscriben. Seguidamente, estudiaremos la construcción del discurso del paraíso, como uno de los temas y estrategias que comparten ambos textos.

\section{BREVE DESCRIPCIÓN DE LAS NOVELAS Y SU MARCO LITERARIO}

\subsection{La novela rosa de Nancy Kennedy (1979)}

Secret Longings (en adelante, $S L$ ) es una típica novela rosa, subgénero literario que, aunque denostado por la crítica por su doble condición de popular y femenina (Sánchez-Palencia, 1999), continúa alimentando a la rama más poderosa de la industria editorial, por sus elevados índices de venta a nivel mundial. La autora sigue las pautas del género para narrar la historia de amor de Holly Hutchinson, secretaria discreta y de aspecto impecable de la firma de abogados Fleming, con sede en San Francisco. Holly se ha ganado hasta tal punto la confianza de su jefe, Dwight Fleming, que este no duda en encomendarle una misión de carácter privado y de intriga familiar: que acompañe, en calidad de supuesta 'prima', a su hijo Larry en su viaje a Canarias para conocer a la familia de la que aspira a ser su prometida, Carlotta, y pedirla en matrimonio. Holly deberá informarle acerca de la misteriosa joven canaria que Larry ha conocido durante una estancia en Londres y con la que pretende casarse. Le urge saber si se trata de una típica cazafortunas o si, por el contrario, está realmente enamorada del que resulta ser el único hombre al que Holly secretamente ama. La historia se complica con la aparición en escena de Bennet, el enigmático hermano (adoptado) de Larry que, al parecer, conoce bien a Carlotta y quiere evitar el matrimonio. Además, Bennet se da cuenta del amor secreto que Holly siente por Larry y la anima a luchar por sus sentimientos y salvar a Larry de

${ }^{3}$ El volumen incluye tres secciones adicionales: la primera, titulada From the author's notes, reproduce doce fotografías tomadas durante las tres estancias de Gunn en Gran Canaria; la segunda ofrece ocho preguntas para que el lector reflexione sobre diversos aspectos del argumento de la novela; por último, hay una entrevista con la autora. 

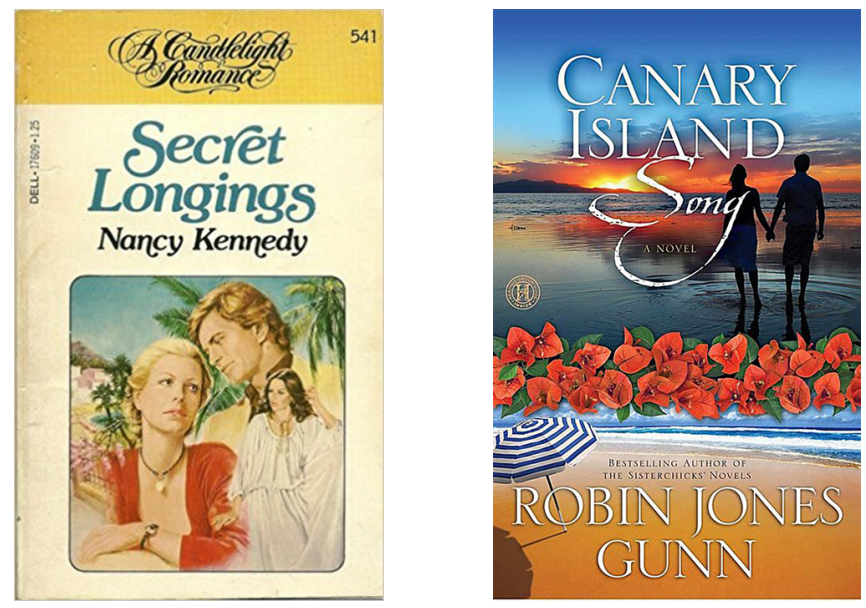

las garras de la interesada Carlotta y su familia. Finalmente, el argumento se centra en cómo Holly, durante su estancia en la isla, tiene que lidiar con sus sentimientos hacia los dos hermanos y descubrir poco a poco que en su corazón Larry, el hombre que ella pensaba que amaba, va cediendo el sitio a Bennet, que es a quien realmente ama. Así se resume esta historia de dos hermanos que da un giro para conseguir el final feliz reglamentario en toda novela rosa.

\subsection{La novela ChiCKLIT De Robin Jones Gunn (2011)}

Canary Island Song (en adelante, CIS) es uno de los más de 100 títulos publicados hasta el momento por esta escritora estadounidense de ideología cristiana ${ }^{4}$, que ha vendido millones de ejemplares de sus novelas chicklit en todo el mundo. Al igual que la novela rosa, este género no está exento de polémica. Su definición no resulta fácil, pues es una categoría muy amplia que admite una gran variedad de textos, a los que a veces solo les une el hecho de que la protagonista principal es una mujer. Puede decirse que este tipo de obra narra el crecimiento personal de una mujer o grupo de mujeres, ya sea en la búsqueda de su príncipe azul o en la lucha por rehabilitarse o aceptar cualquiera de sus adicciones. Suelen aparecer todo tipo

${ }^{4}$ Gunn ganó en 2007 uno de los Christy Awards, premios que se conceden cada año en los Estados Unidos en reconocimiento a la excelencia de aquellas novelas escritas desde una visión cristiana del mundo. Se premian diversos géneros, incluyendo novelas contemporáneas, históricas, obras de suspense y también novelas románticas. 
de personajes, enfrentándose a problemáticas que impiden que el público lector se identifique con ellos como héroes o heroínas, aunque sí que se ganan su simpatía. En palabras de Bell (2013), la categoría chicklit incluye:

light and fluffy romance-novels; laugh-out-loud comedies that have you sniggering on the morning commute; or gritty tales of heartbreak and loss. Whilst the majority have a happy ending, and feature a love story, these aren't prerequisites of the genre. [...] All I want as a reader by the time I see the magic words «the end» appear, is to be left with a sense that the main character's life is infinitely better than it was at the start of the novel.

La novela de Gunn comienza cuando Tikki, la hija veinteañera de la protagonista, propone a su madre que, tras siete años de austera viudedad, debería ir pensando en volver a tener una vida. Este comentario hace mella en Carolyn, quien finalmente decide que ya es hora de salir de su solitaria rutina en San Francisco haciendo una escapada muy oportuna a la casa de su madre en las Islas Canarias. Será una visita sorpresa porque su progenitora está a punto de celebrar su 70 cumpleaños. Sin embargo, el viaje conllevará también una sorpresa para Carolyn, pues en ese evento va a reencontrarse con Bryan Spencer, su antiguo amor de verano, cuando ambos adolescentes visitaban durante las vacaciones a sus familias isleñas.

El cariño entrañable de su madre y sus tías, todas ellas mujeres canarias, junto con la belleza y la música de las islas, harán que Carolyn recupere ese sentido de plenitud de la vida, así como su corazón, perdido tras la trágica muerte de su marido. Al igual que Cristóbal Colón partió desde Gran Canaria en 1492 en un viaje que le llevaría a descubrir el Nuevo Mundo, Carolyn parece estar preparada para volver a navegar desde esta misma isla rumbo a su nueva vida.

\section{EL DISCURSO DEL PARAÍSO: ANTECEDENTES Y DISCUSIÓN}

En esta sección mencionaremos algunos trabajos que han abordado el estudio del discurso del paraíso, explicando el origen de este tema. Tras mostrar la relevancia de Canarias en este campo, estudiaremos las novelas seleccionadas, ilustrando las estrategias con las que este tipo de discurso se va construyendo en ambos textos.

\subsection{ESTUdios SOBRE EL DISCURSO DEL PARAÍSO: BREVE REVISIÓN}

El concepto del paraíso existe en la mayoría de las culturas y religiones. Está presente también en el arte y en la literatura universal, como símbolo de un estado, una condición del alma (James 1988). Tiene que ver con el tópico del locus amoenus, la descripción de lugares agradables, paisajes idílicos, la naturaleza feliz con sus bellas imágenes de jardines, flores, pájaros, brisas cálidas y arroyos (Baehr 1991). Esta conexión entre la felicidad y los jardines procede de la mezcla de tradiciones grecolatinas con las escenas bíblicas de los jardines del Edén, que mostraban una vida feliz en un lugar privilegiado del planeta, donde la generosa abundancia 
de la naturaleza se vinculaba con el agua, con agradables fragancias y un clima de eterna primavera, con la ausencia de sufrimiento y con la paz y armonía entre todos los seres, humanos y animales (Delumeau 1995). Así se fue formando el mito del paraíso, que ha pervivido en muchas culturas.

En el caso de Canarias, son muchos los investigadores (Cabrera-Perera 1988, Even 1963, Martínez 1992, Tejera 1991, entre otros) que han estudiado la relación de las islas con los mitos y leyendas de los poetas griegos, que las identificaron con los Campos Elíseos, las Hespérides, Islas de los Bienaventurados o Islas Afortunadas, equivalentes al paraíso, donde las almas virtuosas gozaban de un reposo perfecto después de su muerte. Este discurso ha pervivido en los escritos de múltiples autores que a lo largo de los siglos han cantado las excelencias del Archipiélago como un enclave perfecto para el disfrute turístico, para el estudio de su hábitat natural por la gran variedad de especies de su rica flora y fauna, o bien como marco idílico e inspirador de numerosos relatos de viaje y obras de ficción. Toda esta literatura ha contribuido, y continúa contribuyendo, a perpetuar la visión de Canarias como un paraíso en el imaginario colectivo internacional.

\subsection{El DisCURSO DEL PARAÍsO EN LAS NOVELAS}

En $S L$ y CIS la imagen paradisíaca de Gran Canaria parece construirse a través del lenguaje, con las descripciones y las referencias a los lugares donde se desarrolla la acción, ya sean paisajes urbanos o de la naturaleza. Con frecuencia son los narradores quienes describen estas imágenes, pero también los propios personajes vierten abiertamente sus opiniones, haciendo comentarios al respecto. Es un discurso que se manifiesta unas veces de manera directa y otras de modo mucho más sutil, mediante el uso de palabras que sugieren ciertas connotaciones exóticas. Así sucede con la mera referencia inicial a las Islas Canarias, donde vive esa Spanish señorita de la que se ha enamorado el hijo menor de los Fleming en $S L$ (7). En este sentido, una diferencia notable entre los dos textos que aquí estudiamos está en el grado de conocimiento e imbricación con las islas que muestran sus respectivas heroínas. Así, en $S L$, Holly confiesa que no sabe nada acerca de las islas (18), y que nunca había vuelto a pensar en ellas después del terrible accidente aéreo acontecido unos ańos antes en la isla de Tenerife $(85)^{6}$. En cambio, para Carolyn, la protagonista de CIS, Canarias representa sus raíces, pues su madre vivió

5 En realidad, todo lo hispano, incluida la imagen de la mujer española, ha formado un estereotipo de lo exótico y lo pintoresco en la mentalidad anglosajona ( $c f r$. González Cruz-González de la Rosa 1998).

${ }^{6}$ Se refiere al choque entre dos aviones Boeing 747 que se produjo el 27 de marzo de 1977 en el aeropuerto de Los Rodeos (hoy Tenerife Norte), en el que murieron 583 personas. Es tristemente recordado por ser el accidente aéreo con mayor número de víctimas en la historia de la aviación. Obsérvese que $S L$ se publicó en Nueva York en 1979, poco después de este trágico suceso que hizo que Canarias se convirtiera en un triste punto de referencia para muchos estadounidenses. 
allí hasta los 14 años, momento en que toda la familia se traslada a los Estados Unidos. Incluso su hija Tikki, que no había estado nunca en las islas, demuestra sus conocimientos cuando le recriminan:

«... you need to take your daughter to the Canaries. She knows nothing of the islands».

«Yes, I do,' Tikki protested. 'I know that Cristopher Columbus set out from Las Palmas in 1492 when he sailed the ocean blue».

«Everyone knows that. But do you know where the Canary Islands are located?». "Of course I do. They're off the coast of West Africa. See? I know where my blood is from - mi sangre» (17).

Hay que señalar que la palabra isla ya evoca ciertos conceptos en la mente del lector continental, que tiende a asociar lo insular con lo paradisíaco y con lo exótico. Esta idea, basada en la mitología insular de la Grecia clásica, dio lugar a la creencia popular, generalizada a partir del siglo XIII, de que «las maravillas más espectaculares y las tierras más exóticas están en islas misteriosas y lejanas» (Aínsa 2001: 19). Por otro lado, en ambas novelas el uso de hispanismos, como señorita, es una estrategia recurrente ${ }^{7}$; estas voces desempeñan distintas funciones sociopragmáticas (González Cruz 2018) en los textos y aportan cierto "color local» a la narrativa, al tiempo que contribuyen no solo a caracterizar a los personajes isleños sino también a maximizar en el lector anglosajón la percepción de un lenguaje que le es ajeno y extraño, resultándole por ello pintoresco y, en definitiva, exótico. Pero ese exotismo se va configurando sobre todo con las referencias constantes a elementos del paisaje, como las montañas, los volcanes, el mar, la flora, el drago milenario y las leyendas a él vinculadas, las fincas de plataneras, el paseo en camello por las dunas con su evocación de la cercanía de África y el desierto del Sáhara, el clima y la agradable temperatura, e incluso la alusión a la historia, a todo lo que nuestros protagonistas estadounidenses perciben como antiguo, propio del Viejo Mundo, incluyendo, cómo no, la conexión de la isla con Cristóbal Colón y sus viajes de descubrimiento, rememorados en la Casa y Museo colombinos de la capital grancanaria. Así, en $S L$, a su llegada en coche a la capital grancanaria, Holly señala que Las Palmas le parece una ciudad interesante, más moderna de lo que esperaba, y expresa su fascinación al saber, por boca de su anfitriona, la señora Navarra, madre de la novia canaria de Larry, no solo que son una de las familias más antiguas de la isla, sino que el distrito de Vagueta $[\mathrm{sic}]^{8}$ guarda los monumentos históricos más relevantes, con las casas de los primeros gobernadores y la catedral, cuya construcción se inicia en 1497.

${ }^{7}$ La tendencia a incorporar hispanismos que se aprecia en todas las obras del corpus es muy típica también de la literatura de viajes (cf. Castillo 2010, 2017; Castillo y Díaz Alayón 2009; Corbella 1991; Curell 2001; González Cruz 2011b, 2013; Tabares et al. 2009, entre otros).

${ }^{8}$ Así se denomina en todo el libro, al igual que el apellido de la familia, Navarra, en lugar de Navarro. 
The limousine was now approaching a very old district of the city, quaint, picturesque, and awash with the old-world atmosphere she had felt in Madrid, but here completely so; another world, indeed. 'Oh, how lovely!' she murmured [...]. Holly [...] let her eyes take in the many balconies that overlooked the narrow street the limousine had turned on to, the peaceful patios, and all-but-hidden small plazas (44).

De hecho, el barrio de Vegueta y la Casa de Colón, junto con la playa de Las Canteras, son algunos de los lugares emblemáticos de la capital grancanaria que los protagonistas de ambas novelas visitan y sobre los que encontramos comentarios en los dos textos. Así, sobre el primer recorrido a pie que Holly hace, junto a su anfitriona, por el barrio antiguo de Las Palmas, leemos:

The walk with Señora Navarra proved interesting, and Holly rather enjoyed herself, although she would have preferred a different guide. The señora's pushing pride in the ancient district took the edge off Holly's appreciation, but there was much to see. The Casa de Colón, residence of the first island governors, was beautifully preserved, and a grand museum of the Columbian period, to which the Señora devoted much time, was an experience - the $16^{\text {th }}$ century cathedral alone was worth any trip by a tourist, as Holly remarked $(S L, 69)$.

SL presenta además otro de los encantos del barrio antiguo de Las Palmas, relacionado con las celebraciones religiosas: las alfombras de flores. Ocurre cuando, en otro paseo por la ciudad, Theresa, la otra hija de la señora Navarra, con quien Holly simpatiza más, la lleva a la Plaza de Santa Ana, "the great central plaza of the city». La norteamericana queda impresionada con su belleza:

The sight that met her eyes wiped out any other consideration. Stretching across the entire length of the plaza, from one fine old building to another, was an unbelievably beautiful carpet of flowers in intricate, repeated designs on a long mat of manicured grass. The colors were breathtaking, and Holly declared over and over that she had never seen anything like it. [...] Holly couldn't take her eyes -wide with delight- away from the long, exquisite sight (98-99).

También en CIS se alude a la belleza del distrito de Vegueta y a la fascinación por el valor histórico de la Casa de Colón. Carolyn no oculta su emoción ("This is amazing!») al ver que se encontraba al otro lado del mundo, «standing in a place where history had unfolded hundreds of years ago» (213). Igualmente, al ver la capilla donde oró Colón en 1492, Carolyn no encuentra palabras para describir los sentimientos que le inspira el lugar:

Being here, stumbling on this 'holy place' felt like she had come upon a treasure chest. [..] It thrilled her to think that while unknown worlds awaited Columbus on the other side of the Atlantic, before he set sail, he came here, to this humble chapel, and he prayed. [...] For Carolyn this was like stepping into world history (214-215).

De hecho, Carolyn plantea cierta analogía entre su viaje y el del famoso descubridor del Nuevo Mundo. Así, en momentos de inquietud siente el ferviente deseo de ir a rezar a esa misma capilla: 
Carolyn got ready for bed and wished she could go to the chapel where Columbus prayed. She would there right now if she knew for sure she could get inside. She would pray, as Columbus did before he started his journey into unknown waters. Her prayers would be for blessing and protection and for the fear to go away $(252-253)$.

Igualmente, en una de las ocasiones en las que almuerza en un conocido restaurante de la avenida de Las Canteras, reflexiona así:

... she looked out at the sand and the water, once again feeling that sense of timelessness here where life's elements were at their most basic - sun, wind, sand, sea. She paused to wonder if Columbus had ever come to this exact bay and beach when he was on the island. What other explorers or pirates had left their footprints in this sand in this place of soft, dusty tenacity? (191).

Ante la paradisíaca visión de la playa de Las Canteras, ambas autoras emplean calificativos que intentan reflejar los sentimientos que la belleza del lugar inspira en los personajes:

They reached Las Canteras, a marvelous beachland of white sand and, obviously, great popularity. The weather was perfect and, beyond the seemingly endless stretches of beach, the bay itself was like a giant swimming pool, protected from the breakers by a natural barrier $(S L, 86)$.

Heading for the beach, Carolyn stopped as soon as she came into view of the wide, sandy bay and drew in the scent of the sea. [...] Here, at the Las Canteras beach, time had stood still. Everything was exactly as she remembered. Rows of neatly lined-up lounge chairs awaited customers within a roped-off section in front of a blue-and white striped cabana. A gathering of palm trees clustered beside the boardwalk and seemed to sigh with their own memories as the breeze rose to ruffle them.

Carolyn slipped off her sandals and buried her bare feet in the warm sand. She smiled at the way the sunlight sparkled on the clear, green water with an ageless verve. Along the shoreline, the Atlantic calmly curled and receded like a curtsy, leaving a fine white line of foamy petticoat lace on the tawny sand.

A vivid memory of her first visit to this beach rose to the surface of her thoughts (CIS, 87).

Pero hay otros lugares de Gran Canaria que también se describen en las obras. Así, durante el trayecto para visitar su finca de plataneras en la zona de Arucas, Bennet, el héroe de $S L$, explica a Holly cómo el turismo ha provocado la construcción de numerosos hoteles y urbanizaciones, que han ejercido su impacto en la economía. Y añade: "but there is still much that remains untouched. You'll see for yourself, and I've a feeling it's the real Canary Islands you want to know» (85). Holly comprueba que la pequeńa ciudad de Arucas es un lugar precioso, que describe como «a lovely town with exotic flowers and fine palm groves» (75).

En CIS la pareja visita Maspalomas y da un inolvidable paseo en camello por las dunas; y leemos: «They were up! And what a view. The sand dunes stretched out before them, and beyond the dunes lay the sea. The vista made it easy to believe 
that only fifty miles to the east was the coast of West Africa and the Sahara Desert» (273). Además de evocar la cercanía del continente africano, la experiencia de este exótico paseo de ritmo tranquilo dejaría en Carolyn importantes reminiscencias de todo lo esencial y lo simple de la vida:

With an easy tilt and a steady lilt, the journey into the sand dunes began. Carolyn felt her shoulders relax. She remembered this unhurried pace as one of her treasured memories of the Canary Islands. They seemed to have been transported through time to a place where only the basic elements of life existed. In such an uncomplicated place, she could readily distill her thoughts to only the ones that mattered (274).

Por su parte, la pareja protagonista de $S L$ hace una escapada a Tenerife, Lanzarote y El Hierro en el barco de Bennet, quien manifiesta el excelente espíritu turístico que le inspiran las islas al decir: "I'd be hard put to say which of the islands, outside of Hierro, I prefer» (131). Por su parte, la heroína comenta: «I'm just basking in all this lovely weather. I don't remember ever seeing the sky so blue» (32). En Tenerife visitan el famoso y enigmático drago milenario de Icod, «reputedly a very romantic spot» (130). Su contemplación hace llorar de emoción a Holly, lo que Bennet justifica diciendo: "I've heard that this old tree affects people differently" (134). Más adelante, al contar la experiencia a Larry, este le hace comprender el significado que tiene para los canarios la visita al drago de Icod, un árbol que Holly califica de «unbelievable, just magnificent» (137). Se trata de una superstición de la que le había hablado Carlotta en los siguientes términos: «It's supposed to mean, you know, guys only take girls they are serious about there, and it's supposed to bring good luck to the couple, something like that. Carlotta says it's where couples pledge their troth. Isn't that a funny old-fashioned expression?» (137).

$\mathrm{Al}$ aproximarse a la isla de El Hierro, la visión es idílica:

... the smallest of the Canary Islands was broken and mountainous, with cliffs dropping right down into the sea except at the entrance to the gulf. Here the shores were wooded, mostly with the evergreen of pine trees, and the main town, Valverde, [...] lay nestled in the arms of the encircling mountains. [...] The very smallness of the island enchanted Holly. [...] The town that faced the sea between the high mountains was lovely, [...] and beyond the land was dotted by beautiful farms and gardens. [...] It was, Holly decided, a very friendly place (116-118).

La fascinación que sienten hace que al final de la novela vuelvan a hacer referencia a esta isla y la incluyan en sus planes futuros de vida en común:

«You liked Hierro island, didn't you?».

«What? Oh. Yes, I loved it. Why?».

«I'll never sell our summer home there. We could come back from time to time for a visit. You'd like that, wouldn't you?» (191).

La visita a la Montaña de Fuego en Lanzarote también les asombra por la misteriosa apariencia lunar del paisaje y el cultivo de viñas, que demuestra «man's 
genius at survival» (178). Los enamorados comprueban todos los atractivos del lugar, pasean en camello, almuerzan en el Restaurante El Diablo, donde la carne es asada con el calor que desprende el suelo, por la actividad térmica volcánica cercana a la superficie. Entusiasmada con el entorno, Holly exclama: «One could easily imagine one's self on a different planet [...] That's ash all around us, isn't it? [...] I can't tell you how glad I am you brought me» (179-180).

Ambas novelas ofrecen comentarios directos acerca del carácter paradisíaco y exótico de las islas. Así, en CIS, cuando Carolyn regresa a los Estados Unidos para vender su casa y despedirse de sus compañeros de trabajo en la escuela de primaria, el jefe de Estudios le comenta: «You know, don't you, [...] the rest of us are wishing we had an exotic place to run off to like you» (277). Igualmente, en $S L$, durante el viaje en barco por las islas, Bennet señala que las considera "a vacation paradise» (132). Pero, como hemos visto, abundan mucho más los comentarios sugerentes que, de manera indirecta y subjetiva, van esbozando en la mente del lector imágenes paradisíacas que se filtran con ligeros trazos entre las descripciones y la narración de la acción, como estos que tomamos de CIS:

... the memories had come at her fast and vibrant. She remembered the camel ride as well as the sun-drenched afternoons on the beach at Las Canteras, the shimmering sea and the first time Bryan held her hand. For a glimmer of a second Carolyn could see it all: the star-filled sky overhead, the rough side of the overturned green fishing boat, and Bryan waiting for her (18).

Their leisurely morning continued, accompanied by melodious birdsongs from Alma and calm breezes coming through the open windows along with an interesting mix of muted guitar music from an apartment nearby. Life here felt simple and unhurried. Carolyn could see now why her mother made the big decision to leave the Bay Area after Carolyn's father passed away to move back here. This tempo fit her mother's personality. This place composed a day-to-day music that Carolyn's mother knew by heart. She fit here. This was her home (119).

\section{CONCLUSIÓN}

Aunque estrictamente no pertenezcan al género de viajes, creemos que, por sus características, las novelas románticas aquí analizadas constituyen una interesante contribución al patrimonio bibliográfico hispano-norteamericano. Con todo lo expuesto esperamos haber demostrado su utilidad para el estudio de la representación de España en los Estados Unidos. Mediante las descripciones y comentarios directos e indirectos que hemos recopilado, Secret Longings y Canary Island Song consiguen evocar en el lector la típica visión un tanto estereotipada de este archipiélago español como un paraíso. Pensamos además que, dada su gran popularidad y elevado número de lectores en todo el mundo, este tipo de literatura romántica que incluye viajes a las islas ha contribuido y seguirá contribuyendo a la construcción y difusión del imaginario internacional de Canarias como un enclave paradisíaco. 


\section{BIBLIOGRAFÍA}

Aínsa, Fernando (2001): «Las ínsulas de 'tierra firme' de la narrativa hispanoamericana. Entre la memoria y la esperanza», en Carmen Alemany Bay et al. (eds.), La isla posible. III Congreso de la Asociación Española de Estudios Literarios Hispanoamericanos, Alicante: Universitat d'Alacant y AEELH, Biblioteca Virtual Universal, 17-25.

Baehr, Stephen L. (1991): The Paradise Myth in 18 ${ }^{\text {th }}$ Century Russia, Stanford: Stanford University Press.

Balbuena, José Manuel (2007): La odisea de los canarios en Texas y Luisiana, Las Palmas de Gran Canaria: Anroart Ediciones.

BeLL, Anne (2013): «What is chicklit?». URL: https://bookriot.com/2013/02/11/what-is-chick-lit/.

Bethencourt Massieu, Antonio (1991): Canarias e Inglaterra: el comercio de vinos, 1650-1800, Las Palmas de Gran Canaria: Cabildo Insular de Gran Canaria.

Cabrera-Perera, Antonio (1988): Las Islas Canarias en el mundo clásico, Madrid: Viceconsejería de Cultura y Deportes. Gobierno de Canarias.

Castillo, Francisco Javier (2010): «Las hablas insulares en la literatura inglesa de viajes», en Dolores García Padrón y María del Carmen Fumero Pérez (eds.), Tendencias en lingüistica general y aplicada, Frankfurt am Main: Peter Lang, 53-62.

Castillo, Francisco Javier (2017): «Literatura de viaje y descripción lingüística. Las notas de Margaret D’Este sobre el habla canaria», en A. Díaz Galán y M. Morera (eds.), Estudios en memoria de Franz Bopp y Ferdinand de Saussure, Frankfurt am Main: Peter Lang, 49-62.

Castillo, Francisco Javier y Carmen Díaz Alayón (2009): «Notas lingüísticas», en Canarias en la Europa Ilustrada: el legado de George Glas, La Laguna: Centro de la Cultura Popular Canaria, 121-125.

Corbella, Dolores (1991): «Hispanismos en la obra de Adolphe Coquet: Une excursion aux Îles Canaries», en Roberto Dengler Gassin (ed.), Estudios humanisticos en homenaje a Luis Cortés Vázquez, Salamanca: Ediciones Universidad de Salamanca, 137-145.

Curell, Clara (2001): «Hispanismos en los libros de viaje franceses del siglo xviII», en Isabel Uzcanga Vivar, Elena Llamas Pombo \& Juan Manuel Pérez Velasco (eds.), Presencia y renovación de la lingüistica francesa, Salamanca: Ediciones Universidad de Salamanca, 99-107.

Davies, P. N. (1987): «The English Contribution to the Economic Development of the Canary Islands with Special Reference to the Nineteenth Century", Actas del VI Coloquio de Historia Canario-Americana, tomo III, Las Palmas de Gran Canaria: Cabildo de Gran Canaria, 353-379.

Delumeau, J. (1995): History of Paradise. The Garden of Eden in Myth and Tradition, Nueva York: Continuum Trad. Matthew O'Connell.

Din, Gilbert C. (1999): The Canary Islanders of Louisiana, Baton Rouge, LA: Louisiana State University Press.

Even, Yann (1963): The Canary Islands. Mythical, Historical, Present, Santa Cruz de Tenerife: Lit. Romero.

Fernández-Armesto, Felipe et al. (1995): Canarias e Inglaterra a través de la historia, Las Palmas de Gran Canaria: Cabildo Insular de Gran Canaria.

García Pérez, José Luis (1988): Viajeros ingleses en las Islas Canarias durante el siglo XIX, Santa Cruz de Tenerife: Confederación Española de Cajas de Ahorros. 
GonzÁlez Cruz, M. ${ }^{a}$ Isabel (1995): La convivencia anglocanaria. Estudio sociocultural y lingüistico, 1880-1914, Las Palmas de Gran Canaria: Ediciones del Cabildo Insular de Gran Canaria.

GonzÁlez Cruz, M. ${ }^{a}$ Isabel (2002): Notas para una bibliografía inglesa sobre Canarias, La Laguna: Instituto de Estudios Canarios.

GonzÁlez Cruz, M. Isabel (2006): «Realidad y ficción en Grand Canary, la novela de A. J. Cronin en Tenerife», en Francisco Morales Padrón (coord.), Actas del XVI Coloquio de Historia CanarioAmericana, Las Palmas de Gran Canaria: Cabildo de Gran Canaria / Casa de Colón, 1061-1075.

GonzÁlez Cruz, M. ${ }^{a}$ Isabel (2008): «La visión de Canarias en Tales of the Fortunate Isles (1959) de Paul Eldridge», en Francisco Morales Padrón (coord.), Actas del XVII Coloquio de Historia Canario-Americana, Las Palmas de Gran Canaria: Cabildo de Gran Canaria / Casa de Colón, 1495-1508.

GonzÁlez Cruz, M. a Isabel (2009): «Canarias, siglo xx: la imagen de las islas en tres obras publicadas en Nueva York», Estudios Canarios. Anuario del Instituto de Estudios Canarios, 53: 11-41.

GonzÁlez Cruz, M. Isabel (2010): «La visión de Gran Canaria en Canary Island Adventure. A Young Family's Quest for the Simple Life (1956) de Richard Walter», Actas del XVIII Coloquio de Historia Canario-Americana, Las Palmas de Gran Canaria: Cabildo de Gran Canaria / Casa de Colón, 602-614.

GonzÁlez Cruz, M. ${ }^{a}$ Isabel (2011a): «Un nuevo registro para la bibliografía inglesa sobre Canarias: el texto de Alice Carter Cook (1900) sobre los aborígenes canarios", Estudios Canarios. Anuario del Instituto de Estudios Canarios, 55: 13-63.

González Cruz, M. ${ }^{a}$ Isabel (2011b): «Exploring the Canarian contribution to Hispanicisms in English", Revista Alicantina de Estudios Ingleses, 24: 131-152.

González Cruz, M. ${ }^{a}$ Isabel (2013): "Hispanismos y canarismos en un corpus de textos ingleses sobre Canarias", LEXIS. Revista de Lingüistica y Literatura, 37 (2): 229-267.

GonzÁlez Cruz, M. ${ }^{a}$ Isabel (2018): «Hispanismos en el discurso romántico de Harlequin y Mills \& Boon. Ámbitos temáticos y funciones socio-pragmáticas», Moderna Sprak 1: 157-178.

GonzÁlez Cruz, M. Isabel y M. a del Pilar GonzÁlez de la Rosa (1998): «Dimensions of the Intercultural Within Travel Literature: British Images of Spain», en Santiago Henríquez (ed.), Travel Essentials, Las Palmas de Gran Canaria: Chandlon Inn Press, 43-61.

GunN, Robin Jones (2011): Canary Island Song, Nueva York: Howard Books.

James, Nancy E. (1988): «Two Sides of Paradise: The Eden Myth According to Kirk and Spock», en D. Palumbo (ed.), Spectrum of the Fantastic, Nueva York: Greenwood Press, 219-223.

Kennedy, Nancy (1979): Secret Longings, Nueva York: Dell.

LipsKi, John M. (1990): The Language of Isleños: Vestigial Spanish in Louisiana, Baton Rouge: Louisiana State University Press.

Martínez, Marcos (1992): Canarias en la mitología. Historia mítica del archipiélago, Santa Cruz de Tenerife: Centro de la Cultura Popular Canaria.

Pérez, Samantha (2011): The Isleños of Louisiana. On the Water's Edge, Charleston, SC: The History Press.

Sánchez-Palencia, Carolina (1987): El discurso femenino de la novela rosa en lengua inglesa, Cádiz: Publicaciones de la Universidad de Cádiz.

Santana Pérez, Juan Manuel y José Antonio SÁnchez Suárez (1993): Emigración por reclutamientos. Canarios en Louisiana, Las Palmas de Gran Canaria: Universidad, Servicio de Publicaciones. 
TABARes, Encarnación, et al. (2009): «Léxico hispánico en escritos decimonónicos en lengua alemana sobre Canarias», en M. ${ }^{a}$ Josefa Reyes (coord.), Léxico y cultura, Badajoz: @becedario, 205-310.

Tejera, Antonio (1991): Mitología de las culturas prehispánicas de las Islas Canarias, La Laguna: Secretariado de Publicaciones. Universidad de La Laguna. 